\title{
LA HUERTA DE ALICANTE TRAS LA GUERRA DE LOS DOS PEDROS. ACERCA DE LA CONSTRUCCIÓN DEL ASSUT NOU EN 1377
}

\author{
José Vicente Cabezuelo Pliego \\ Sonia Gutiérrez Lloret \\ Universidad de Alicante
}

Este trabajo tiene como objeto principal presentar un interesante documento de singular importancia para la historia del espacio agrícola vinculado a la ciudad de Alicante y conocido como la uerta de Alicant dalcobra (1) $u$ orta Aliquantis. En dicho documento, depositado en el Archivo Municipal alicantino, el rey Pedro IV, ante la súplica realizada en 1376 por algunos habitantes de la villa de Alicante, dispone la construcción de un azud y de una acequia nueva en la mencionada huerta, con el fin de ampliar considerablemente la superficie irrigada. Dicho azud debía emplazarse en el cauce del río Montnegre (2), aguas abajo del assut vell o azud de Muchamiel, con el objeto de recoger las aguas que dicho azud no podía contener, a más de aprovechar los aportes esporádicos de los barrancos de Agua Amarga y Vercheret, que desembocan en el río Montnegre por debajo del azud de Muchamiel y cuyas apreciadas aguas se perdían necesariamente en el mar. La realización de la obra, que había sido ya planeada en época del infante don Fernando, aunque nunca llevada a término, fue aprobada el 21 de junio de 1377 previa visura y demarcación de su discurrir por parte de un maestro nivelador traído a tal efecto desde Xàtiva. Nicolau de Pròxida, gobernador de las tierras allende Jijona, juez y comisario de la obra, 
dispuso que los costes de la misma habían de ser sufragados por los propios alicantinos, acordando cuatro mil sueldos anuales hasta su conclusión y añadiendo a tal suma todas aquellas cantidades que eran adeudadas a ese Consel/ municipal; además, se reservó la posibilidad de poder imponer tallas entre los que se beneficiarian de la dicha obra para que ésta fuese terminada en un menor plazo de tiempo. Dispuso también que el agua contenida en el azud y acequia nuevos podría ser partida en razón a unos capítulos que se realizarían con ese fin; si bien, la utilización de esta construcción no debería perjudicar en nada al mantenimiento de la acequia y azud primitivos, como ya indicaba Pedro IV el año anterior -22 de octubre de 1376- cuando concedió licencia para ello.

La planificación de esta obra debe ponerse en relación con la reactivación económica impulsada por la Corona tras la guerra de los dos Pedros, que había asolado el alfoz alicantino en las primeras décadas del ecuador del siglo XIV, provocando la práctica destrucción del espacio agrícola de por sí frágil, con la tala de especies arbóreas, la quema de las cosechas, la desorganización de la red de riego y la dispersión de la mano de obra (3).

La información que aporta el documento es variada y permite aunar dos líneas de investigación histórica sobre los espacios agrarios que creemos deben caminar unidas y que habían preocupado a cada uno de los autores de estas páginas: de un lado, aquélla puramente histórica construida con fuentes estrictamente documentales, que estudia las formas de tenencia de la tierra, las normativas jurídicas de distribución del agua, la producción o el impacto de la guerra (4); de otro lado, aquélla que intenta, desde la perspectiva de la historia, o mejor, de la arqueología del paisaje y del territorio, reconstruir los espacios agrarios y su funcionamiento para conocer mejor los mecanismos de transformación histórica (5). Para comprender lo que supone la planificación de dicha política hidráulica es necesario centrar nuestro análisis en tres aspectos distintos: en primer lugar, lo que fue la huerta antes de la guerra de los dos Pedros; en segundo lugar, lo que tal contienda supone para este espacio y por último la planificación del azud en el marco de la recuperación a fines del siglo XIV.

\section{LA HUERTA DE ALICANTE: ORIGEN, PLANIFICACIÓN Y EVOLUCIÓN DE UN PERÍMETRO REGADO}

La reciente publicación de un trabajo realizado por uno de los autores que firman este estudio (6), nos libera de tratar prolijamente algunos de los 
aspectos allí desarrollados. No obstante, es necesario señalar que el origen de la huerta es sin duda islámico, como se desprende del léxico y reglamentación de las formas de distribución social del agua. Dicha reglamentación sólo puede ser inferida a través de los textos cristianos y parece lógico que fuera mantenida en el primitivo reparto realizado por Alfonso $X$ con posterioridad a la conquista y anotado en un libro que concedió al Concejo de Alicante en 1258 (7), como ocurrió en otras huertas mejor documentadas y también vinculadas a la Corona de Castilla (8). Esta primitiva reglamentación, estudiada por A. Alberola (9), supone un sistema dual de regadío, basado en el aprovechamiento de las aguas corrientes y de las esporádicas; el caudal del río se dividía en 336 hilos, reunidos en grupos de 16 hilos diarios de hora y media de duración, divididos a su vez en dos turnos de 8 horas. El conjunto se organizaba en tandas o martabas -del árabe martabat, jerarquía o categoría- de tres semanas en las que se regaba por rigurosos turnos; uno matutino y otro vespertino. Este caudal estable estaba vinculado en origen a la tierra y a diferencia del pluvial, que era esporádico, no podía venderse.

Sin embargo, hay que advertir que esta primitiva reglamentación nos es únicamente conocida por referencias tardías, procedentes de tratadistas que escribieron a principios del siglo XVIII (10) y que son responsables en buena medida de algunas afirmaciones sobre el derecho de aguas de la huerta que, a pesar de su falsedad, se continúan aceptando en la bibliografía especializada. Es el caso del supuesto derecho que Alicante tiene sobre el uso exclusivo del caudal del río y de las aguas pluviales que lo alimentaban en su cabecera, en virtud de un supuesto privilegio que el rey Alfonso $X$ otorgó el mismo año que ratificó en Valladolid el reparto de los heredamientos (11). Como ya señalamos en otro lugar (12), tal derecho no consta en ningún privilegio expedido en 1258 ni en ninguna otra fecha y más parece, como ya indicara el propio $F$. Verdú (13), una extensión equivocada y, por supuesto interesada, de otros privilegios para justificar la apropiación de un bien tan preciado como escaso para la huerta: el agua.

En cualquier caso, el diseño de la primitiva estructura de regadío es de época islámica y utiliza como punto de partida un azud que permite recoger parte del caudal del río Montnegre. De este azud, designado como "antiguo" en el documento que aquí presentamos, arranca toda la red de riego, vertebrada por la acequia principal -cequie veteris- de la que surgen los brazales e hijuelas que llevan el agua a toda la huerta. Este primitivo azud, del que no quedan restos constructivos, debía situarse en el lugar que ocupa el actual azud de Muchamiel, cuya fábrica visible corresponde a la reconstrucción de finales del siglo XVIII, de la misma forma que la acequia vieja es la actual 
acequia Mayor, que atraviesa el municipio de Muchamiel hasta llegar a San Juan.

Este espacio regado originario, es decir, aquél planificado en época islámica, se limitaba a la parte alta de la huerta y ocupaba el sector situado en la margen derecha de la acequia Mayor, llegando como máximo al municipio de San Juan (14). Resulta difícil saber qué brazales son los de origen islámico, pero por eliminación de aquéllos que con certeza no lo son, se deduce que pudieran serlo los cinco primeros de la margen derecha-Alfaz, Albercoquer, Torre o Carnicería, Canelles o Lloixa y Racó- y el primero de la margen izquierda -Aljucer o Benitía-, el único que atraviesa la acequia nueva planificada en 1377, según el documento aquí transcrito. Este último brazal, el de Aljucer o Benitía, tendría en origen la función de actuar como aliviadero del sistema hidráulico en caso de crecida, permitiendo derivar el agua sobrante fuera de la propia huerta.

Este espacio primitivo sufrirá profundas transformaciones con la conquista, siendo las más significativas aquéllas que afectan a la normativa de distribución del agua, que en origen estaba sin duda vinculada a la tierra. El primer reparto, efectuado seguramente tras la conquista castellana, debió quedar recogido en el libro otorgado por Alfonso $X$ y creemos que constituye el conocido por los alicantinos como "libro antiguo". Aunque la incorporación a la Corona catalano-aragonesa no supusiera cambios sustanciales en la ordenación del riego de la huerta, sí los habría de suponer necesariamente en las formas de propiedad que originarían un nuevo reparto, consignado ahora en el "libro nuevo de la partición de las aguas de la huerta", que habría de perderse a raiz de la guerra de los dos Pedros. De forma paralela, comenzará a producirse un paulatino proceso de desvinculación de la propiedad del agua que tenderá a convertirse en un valor en sí mismo, con independencia de la tierra a cuya propiedad había estado ligada en origen; sin embargo, esta creciente especulación en torno a un producto vital para la huerta, alcanzaría su punto álgido a lo largo del siglo XIV, de forma que con posterioridad a la guerra ni la propia Corona logrará ya detener el proceso. Esto que aquí presentamos de modo sintético lo explicaremos y ejemplificaremos más adelante.

\section{EL IMPACTO Y LAS CONSECUENCIAS DE LA GUERRA DE LOS DOS PEDROS}

En la historia de la huerta medieval alicantina las décadas centrales del siglo XIV, aquéllas que se corresponden con la guerra de los dos $\mathrm{Pe}$ - 
dros, suponen una línea divisoria en lo referente al devenir de esa feraz área productiva, reflejan un antes/después de 1356-1366 (15). Las luchas que mantuvieron durante diez años Pedro I de Castilla y Pedro IV de Aragón, III de Cataluña y II de Valencia, y en cuya puesta en escena utilizaron las tierras que hoy se enmarcan dentro de la provincia de Alicante, condujeron a que el fértil espacio agrícola conocido como orta Aliquantis quedase prácticamente destruido, tanto en su vertiente puramente productiva -cultivos- como en lo que atañe a la organización del regadío, y provocaron la dispersión de la mano de obra que lo trabajaba, la mudéjar.

Ya a causa de la primera entrada del castellano en la villa de Alicante, el 8 de septiembre de 1356, la mayor parte de su población, tanto cristiana como sarracena, abandonó el lugar. Idéntico fenómeno acaeció en la huerta. Tal es así que el 7 de diciembre de ese año Pedro IV confirmaba al Consell alicantino unos capítulos concedidos por sus tíos, los infantes don Pedro y don Ramón Berenguer, conquistadores de la plaza para la Corona de Aragón el 30 de octubre anterior, en los que hacía francos a perpetuidad a los mudéjares habitantes de la huerta de "tota peyta", y la razón no era otra que la de asegurar su población y la de la propia aljama urbana (16). De poco sirvió este privilegio, pues sabemos que esas Navidades los infantes don Fernando y don Juan, hermanastros del rey de Aragón y aliados de Castilla, después de haber fracasado en la toma del castillo de Benilloba, y de vuelta hacia sus posesiones oriolanas, "pasaron a correr la vega de Alicante" (17), con lo que debió quedar seriamente afectada, pues la costumbre de los castellanos en sus correrías por tierras de la Gobernación de Orihuela era la de talar los árboles y quemar las cosechas. A mediados de 1359, cuando tras el fracaso naval de Barcelona y de regreso a Cartagena Pedro I amarró su flota unos días en la bahía de Alicante para ganar su castillo, la villa, en palabras de Pero López de Ayala, estaba "yerma é despoblada" (18). ¿Y los campos circundantes? No lo sabemos, pero sí que al poco de finalizar el conflicto la huerta contaba con muy escasa, si no nula, población sarracena, al igual que la aljama urbana, razón por la que el Ceremonioso concedía una franquicia de exención de impuestos reales durante cinco años a todos los mudéjares y judíos que viniesen de lugares con jurisdicción señorial a poblar esa villa (19).

Finalizada la contienda en el año 1366, urbe y huerta comenzaron a recuperar el pulso, aunque muy lentamente. Los destrozos causados por la guerra en las tierras de labor habían sido tantos que Alicante necesitó, aún un año después de concluida, de recuas alimenticias para poder mantener a sus moradores, que de lo contrario amenazaban con marcharse dejando desamparado el lugar (20); dato que subraya la limitada produc- 
ción local, tanto por la destrucción de la tierra y, posiblemente también, de las arterias que la irrigaban (21) como por la liquidación del sistema de propiedad. Lo uno había de recuperarse a medio-largo plazo; lo otro requería la rápida actuación de la Corona a fin de subsanar y poner orden en la caótica propiedad nominal del campo alicantino.

Ya señalamos en un trabajo anterior (22) cómo en las tierras situadas más allá de Jijona, a causa de su proximidad con el reino de Murcia castellano, existía un número importante de propietarios de bienes inmuebles de esa nacionalidad. Y Alicante no era una excepción. Alí apuntábamos de qué modo el inicio de la guerra a finales de 1356 supuso a esos propietarios, vecinos de la ciudad de Murcia en su mayoría, la pérdida de sus posesiones, confiscadas por los oficiales del Ceremonioso por derecho de guerra. De igual modo se conducía Pedro de Castilla. Aunque con una salvedad, cada vez que se producía una tregua los litigantes habían de devolver íntegramente los bienes confiscados a los vasallos del rival. Con esta política pendular evidentemente lo que no se conseguía era una organización de la propiedad de la tierra y un control nominal de la misma. Los cambios se sucedían a un ritmo tan vertiginoso que era imposible cualquier acción positiva en el sentido de mejorar la producción. Un caso revelador quizá pueda ser el de Miquel Sánchez de Linyan, a quien tras la recuperación de la villa por los infantes don Pedro y don Ramón Berenguer, tíos de Pedro IV, a últimos de octubre de 1356, de lo confiscado a los rebeldes le fueron tasados dos mil doscientos sueldos reales valencianos $y$ por ellos asignadas dieciseis tahullas de higuera y de otros árboles y algunas casas que habían pertenecido a Pedro Dolenda, vecino de Murcia y súbdito del rey de Castilla, donación que fue anulada por el infante don Fernando cuando recobró la villa al conceder esos bienes a su vasallo Joan Ximenis de Perencisa; habiendo el justicia de Alicante por orden regia, en octubre de 1366, de obligar a los herederos de éste a devolver esas heredades al susodicho Miquel Sánchez (23).

Al igual que la tierra, la propiedad del agua se vió también afectada por esta dinámica de traspaso de fincas rústicas y urbanas, a lo que hay que sumar su cada vez mayor valor especulativo como bien per se. De este modo, el 28 de septiembre de 1366 Pedro IV se dirigía al justicia de Alicante en lo civil para comunicarle, a súplica de algunos de sus vecinos, a quienes Ramon de Vilanova, tesorero y consejero regio, vendió dieciocho hilos de agua a razón de dieciocho libras reales por cada hilo de los bienes que sus tíos, capitanes generales entonces del reino de Valencia, confiscaron a todos los murcianos. Bienes que el infante don Fernando, una vez que reintegró a su señorío la villa y término de Alicante, concedió a sus do- 
mésticos no obstante las ventas realizadas con anterioridad sobre los mismos. Razón por la que se ordena al justicia alicantino que devuelva esos hilos de agua a sus primitivos compradores, al menos hasta que reciban lo que pagaron por adquirirlos (24).

Esta política de incautación de bienes castellanos tuvo su fin en el verano de 1366, en el mismo momento en el que, sin alcanzar una paz definitiva, las tierras alicantinas fueron reincorporadas a la Confederación catalano-aragonesa. Si bien, la razón sería otra, habiendo de buscarla en los capítulos que firmaron Pedro el Ceremonioso y el entonces conde de Trastámara, posteriormente Enrique de Castilla, por los que se establecía que habrían de ser respetados los bienes que los vasallos de uno tuviesen en el señorío del otro. A este precepto hubieron de acogerse los hijos y herederos de Juan Cortell, vecino de Murcia, quien antes de estallar la contienda poseía en el término de la villa de Alicante diez hilos de agua para regar, propiedad que, una vez comenzada la misma, fue vendida a Mateu Climent y posteriormente concedida por el infante don Fernando a Martí Segarra. Motivo por el cual el 16 de agosto de ese año el rey Ceremonioso ordena a sus oficiales que, obedeciendo dichos capítulos, pongan esos hilos en posesión de los suplicantes (25); volviendo dos días después a ratificar la misma orden (26).

Durante los años siguientes, otros, castellanos y fundamentalmente vecinos de la propia Alicante, a quienes les fueron arrebatadas sus heredades en la huerta, volvieron a recuperarlas, como ocurrió con Pere Celler (27) y Joan Sánchez de Molina (28). Si bien, propiedades que en poco se asemejaban, siempre por defecto, a las que el 14 de febrero de 1370, y tras confiscar los bienes de Juan Guerau, vecino de la ciudad de Murcia, Pedro IV concede a su fiel camarero Simó d'Ampúries (29). Fue encargado Nicolau de Pròxida, gobernador general dellà Sexona, de mantener y defender a éste en su posesión (30); habiendo de actuar en su auxilio meses después cuando, acosado por los acreedores de Juan Guerau, el dicho Simó d'Ampúries vendió a éstos algunos bienes a menor precio del estipulado, por lo que, por orden regia, hubo de obligar a los compradores a devolver esas propiedades y recibir por ellas únicamente el dinero que pagaron (31). Esta propiedad, tal y como ponen de manifiesto Alberola y Giménez (32), localizada a lo largo y ancho de la huerta alicantina, fundamentalmente en la parte baja de la misma, y compuesta por tierras de secano y regadío, alquerías, casas y seis hilos de agua de disfrute perpetuo, supondría importantes rentas una vez puesta en producción. 
El problema todavía no se había solucionado en la década de 1370 . Sabemos que todas aquellas propiedades en la huerta que fueron adquiridas de modo ilegítimo tanto por castellanos como por valencianos súbditos del infante don Fernando durante la guerra con Castilla hubieron, en la mayoría de los casos, de ser devueltas a sus propietarios o a los herederos de éstos. Sin embargo, sabemos también que muchos de los propietarios seculares eran castellanos, algunos de los cuales, por su actuación durante la guerra, larga ausencia, muerte o deservicio al rey de Aragón vieron confiscadas sus heredades como béns vagants. Bienes que pertenecían a la real Corona en virtud de esa situación y que estaban siendo explotados casi fraudulentamente por vecinos de la villa de Alicante. En este punto, y tras conocer Pedro el Ceremonioso algunos de estos casos, acusaba de negligencia a Nicolau de Pròxida, gobernador dellà Sexona, por no haber tomado antes esas propiedades y le ordenaba recabar información sobre el asunto para que en caso de que esos bienes tuviesen que engrosar el real patrimonio los recuperase según "de nostre patrimoni és acostumat de procehir", y fuese diligente para cobrar "ço qui és nostre" (33).

Al compás de las reparaciones en la propiedad de la huerta se fueron realizando otras, tendentes a normalizar el sistema de tandas de riego. El hecho de que se perdiera durante la guerra con Castilla, entre otras escrituras, el Libro de Repartos de agua de la huerta, ocasionó no pocos problemas. Los problemas estribaban en que, una vez finalizada la contienda y ante la falta del mencionado Libro de Repartos conocido como "lo libre nou de la partició de les aygües de la orta" (34), en el que aparecían escritos los nombres de aquéllos que por justo título poseían los hilos de agua, comenzaron a arbitarse las tandas de riego en virtud de lo estipulado en "altre libre que és feyt de loch temps" (35), conocido como "lo libre antich" (36). Libro en el que no se respetaba la propiedad del agua habida antes de iniciarse el conflicto con Castilla, lo que producía grandes pleitos y litigios entre los huertanos por el disfrute de ese preciado bien. Para poner fin a la polémica un martes 20 de julio de 1367 se reunió en la iglesia de San Nicolás el Consell en pleno de la villa de Alicante con Nicolau de Pròxida, gobernador dellà Sexona, al objeto de nombrar una comisión investigadora que determinase a quiénes correspondería el riego en el futuro. Por ello, se ordenó a Pere Sepulcre y a Bernat Vallflor, prohòmens, que junto a los jurados de esa villa "sàpien per sumària informació de bons hómens per sagraments demanats que e quals persones havien, tenien e possehien la dita aygua en lo temps que la dita invasió fon feta e havent-ho axí per la dita informaçió averat tornen a aquells e en llur nom la dita aygua $e$ sabrà qui la dita aygua tindrà". Castigando a aquél que no debiera disfrutar del agua y contradijese lo estipulado por esa comisión con mil sueldos, a emplear en los trabajos de reparación de los muros, y con otros mil a emplear en lo 
mismo a aquél que reivindicase su disfrute no correspondiéndole. Este documento fue ratificado y confirmado por el infante don Juan, primogénito del rey Ceremonioso, el 28 de enero de 1368 (37). Si bien, al parecer, hubo de ser árdua esa tarea, y sin duda larga, ya que en agosto de 1369 , y en un pleito por la propiedad de unos hilos de agua, todavía se aducía la cuestión libre nou/libre vell, no mencionándose en ningún momento resolución alguna sobre el tema presentada por la susodicha comisión; había de ser Nicolau de Pròxida el encargado de dictaminar sobre el asunto (38). Años más tarde, en marzo de 1389, y ya el infante rey, denunciaba como en la huerta habia gran falta de agua, puesto que a pesar de que de antiguo fue partida con la tierra había sido paulatinamente vendida a la Iglesia y a seglares, con gran perjuicio para los dueños de heredades; razón por la que ordenaba al gobernador, al baile general dellà Sexona y al justicia de Alicante que en adelante hiciesen "crida pública" para que nadie pudiese dejar agua a la Iglesia o a religiosos, que nadie la pudiese comprar si no tuviese allí propiedades y que nadie pudiese adquirir más de la que necesitase para regar su heredad "segons les taffulles que seran en la usança de la dita orta" (39).

De todos modos, el éxito o fracaso de todas estas medidas estaba realmente en función de la mano de obra disponible. En este sentido, a pesar de que justo al finalizar la contienda Pedro el Ceremonioso extendió un privilegio de carácter repoblador hacia judíos y sarracenos, éste no logró los resultados esperados. Diez años después, el 27 de agosto de 1376, y ante el estado de desamparo demográfico de la huerta de Alicante, vuelve el rey de Aragón a conceder un privilegio de exención de impuestos durante cinco años a todos los sarracenos, varones y mujeres, que se trasladasen a repoblar esa villa y huerta, si bien, habían de permanecer allí al menos por espacio de diez años (40).

En esta dinámica reactivadora por parte de la Corona, y al amparo de esas mejoras demográficas y de desarrollo económico (41), se inició la construcción por parte del Consell alicantino de una obra que había de suponer la conversión al regadío de una importante franja hortelana, con el consiguiente aumento de la producción especulativa e incremento del numerario en las arcas municipales.

\section{LA PLANIFICACIÓN DEL AZUD Y ACEQUIA NUEVOS EN 1377}

La reactivación económica del alfoz de Alicante pasaba necesariamente por la extensión del espacio regado, con el consiguiente aumento 
de la producción. Sin embargo, cualquier ampliación de un perímetro regado depende de la disponibilidad de incrementar los recursos hídricos que han de alimentar el nuevo espacio, y éste era precisamente el principal problema de la huerta de Alicante. Por este motivo, el proyecto de extensión del regadío por la margen izquierda de la acequia Mayor, y sobre todo por la parte baja de la huerta, requería la planificación de un nuevo sistema de captación de caudales con los que incrementar el ya exiguo regadío de la huerta. La mejor solución era aquella que posibilitaba reconducir a la acequia mayor las aguas pluviales y de avenida, que se vertían al cauce del río Montnegre por debajo del azud viejo y que lógicamente se perdían en el mar. Para ello era necesario construir un nuevo azud aguas abajo del río y una nueva acequia que, a través de una boquera, canalizara los nuevos caudales a la parte más baja de la huerta. Ambas acciones habían sido ya deducidas a partir del estudio espacial de las transformaciones de la huerta (42), pero la lectura del documento que presentamos ha permitido no sólo conocer la planificación de ambas obras, sino también reconstruir el trazado y el diseño de esta importante transformación bajomedieval en un espacio agrícola islámico.

El 22 de octubre de 1376 algunos habitantes de la villa de Alicante con posesiones en la huerta suplican al rey Pedro IV la autorización para la construcción de un azud y acequia nuevos, que sirvieran para recoger y aprovechar toda el agua que de otra manera se confundía con la del mar, sin perjuicio ni deterioro para la acequia vieja. Esta primera alusión a la acequia vieja -es decir, la acequia Mayor- señala ya la duplicidad de intereses entre los antiguos regantes, que toman su agua del azud de Muchamiel a través de esta acequia o de sus viejos brazales -Alfaz, Albercoquer, Torre, Canelles y el Racó-, y los de aquéllos otros que solicitan la nueva obra, propietarios sin duda de las tierras situadas en la parte baja de la huerta, a las cuales el riego tradicional no llegaba; en esta misma línea cabe interpretar la intervención de Francesc Pascual, uno de los vecinos que acompañan al maestro nivelador durante la visura, quien elevó protesta ante el eventual supuesto de que la obra planificada lesionara sus propios intereses, razón por la que requirió que le fuese hecha "carta pública a conservació de son dret e per haver memòria en esdevenidor". En cualquier caso, el rey considera de utilidad ambas obras, por lo que tras ordenar a aquellos propietarios de agua vieja -la que llega por la acequia mayor- que acepten su mandato, dispone que se inicie su construcción a través de tallas, pechas $u$ otras imposiciones.

Asi pues, el domingo 7 de junio de 1377 Nicolau de Pròxida, portantveus de governador dellà Sexona y comisario real de la obra, convocó 
Consell general de la villa de Alicante en la iglesia de San Nicolás. A dicho Consell acudieron las partes contendientes y el común de los vecinos, y allí el gobernador escuchó los alegatos de cada una de ellas, acordándose por mayoría la edificación del azud y de la acequia, así como la búsqueda de un buen nivelador de aguas que los ejecutase. Ese mismo día fue ordenado al notario y escribano del acto que se desplazase a la ciudad de Xàtiva para traer al mejor "maestre que y fos de livelar aygües". El livelador era una especie de agrimensor técnico capaz de proyectar nuevas acequias utilizando sencillos instrumentos de nivelación (43) y de ocuparse del diseño e inspección de cualquier obra relacionada con el regadío; de la especialización de su labor nos da idea el hecho de que para construir la nueva acequia alicantina se buscase a un nivelador en la ciudad de Xàtiva. Una vez en Alicante, Joan Garcia, el maestro nivelador, recorrió junto con numerosos vecinos de la localidad el cauce del río con el fín de hallar la ubicación más adecuada para el azud, jurando ante los Evangelios que realizaría la eleccióm más conveniente y provechosa para la villa y para el rey.

El lugar elegido para su erección fue el mismo emplazamiento en que quiso construirse en época del infante don Fernando, según expusieron algunos vecinos. Se trataba de un lugar donde afloraban tres tormos o cantalls de rocha, llamado lo Conchell y situado debajo del barranco de Matilarany, en dret del partidor llamado también lo Conchell. Las referencias topográficas son especialmente significativas puesto que permiten reconocer el espacio primitivo, a más de recuperar una interesante toponimia; el lugar elegido para emplazar el azud deber ser el mismo que ocupa el actual azud de San Juan, construido entre 1631 y 1633 , sobre afloramientos de roca que permitirían cimentar mejor la obra. Por otro lado, el barranco de Matilarany podría ser una de las ramblas que desembocan en el río entre ambos azudes, es decir, el barranco del Vercheret o el de Agua Amarga. Sabemos que al menos a finales del siglo XIV este paraje se denomina 10 Conchell, quizá por referencia a la cuenca del propio río (44). Desde este punto, el 14 de junio Joan Garcia comenzó a diseñar el trazado de la acequia, buscando el nivel y señalando el recorrido con cruces o fitas, indicando también cuántos palmos era necesario ahondar para nivelar la acequia.

La acequia diseñada parte del lugar donde ha de construirse el azud, atraviesa las propiedades de Na Granulesa y de los herederos de En Bonanat Martí, cruza el partidor de Benitía, y sigue por las heredades de $\mathrm{Na}$ Johaneta, Na Ruberta, En Vidal Gómez, En Nicolau Amat, En Durà y En Rochafort para, bordeando el molí del rey, llegar a la acequia mayor. El itinerario descrito corresponde sin duda al trazado de la acequia del Gualeró 
- acequia nueva de la huerta, que como su nombre indica es claramente un diseño de época cristiana (45). La relación se muestra particularmente prolija en detallar el primer tramo -el comprendido entre el azud y el partidor de Benitía-, mientras que el resto del trazado es descrito muy rápidamente, a pesar de ser mucho más largo. La causa de esta disparidad reside en que es el primer tramo el que mayores dificultades topográficas entraña puesto que hay que salvar un mayor desnivel, siendo por tanto necesario ahondar mucho para mantener el nivel deseado; así pues, antes de llegar al partidor de Benitía habrá sido necesario ahondar treinta y cinco o treinta y siete palmos en algunos lugares, mientras que pasado éste el relieve se suaviza y se mantiene la cota con sólo ahondar entre seis y ocho palmos. De hecho, aún resulta visible en la actualidad la gran profundidad de la impresionante boquera del Gualeró, si bien es necesario señalar que esta acequia, hoy lamentablemente abandonada, sufrió hasta el presente siglo numerosas obras de monda, limpieza y ensanche que debieron alterar su primitiva forma, aunque no su trazado (46).

Uno de los datos más significativos de esta descripción es la mención del partidor de Benitía, lo que confirma nuestra hipótesis de que éste sería el único brazal construido en la margen izquierda de la acequia con anterioridad al trazado del Gualeró y por tanto el único con posible origen islámico. Este partidor corresponde al actual brazal de Benitía o de Aljucer, denominación esta última perdida a fines del siglo XVI (47). No obstante, el brazal de Benitía también podría ser conocido a finales del siglo XIV como el brazal del Conchell, puesto que el documento así parece indicarlo (48). La suma de estos indicios y la evidente relación espacial de los topónimos de Aljucer y lo Conchell con el área próxima al río y al actual brazal de Benitía, permite relacionar ambos topónimos con dos alquerías de la huerta, llamadas de Alconchel y de Aljacer, y mencionadas como límite de una heredad en un documento de 1296 (49). Aunque resulta difícil conocer la entidad de ambos asentamientos, que bien podrían ser únicamente pequeños caseríos, parece posible ubicarlas en este ámbito espacial.

Son también interesantes los datos referidos a la producción de este espacio, ya que la mayoría de terrenos que atraviesa la acequia están plantados de viña, cultivo que sin duda experimentó un gran crecimiento en el siglo XIV. Por último, se menciona un molino del rey, situado en la acequia Mayor, en lo que podría ser el final del sístema hidráulico islámico (50); se trata del molino más antiguo de la huerta documentado hasta el momento, aunque su localización espacial resulta difícil de precisar, puesto que la zona está actualmente muy transformada. 
No obstante, en nuestra opinión la planificación de esta obra -azud y acequia nuevos- era sólo el primer paso de una estrategia de ampliación de la superficie regada, tendente sobre todo a reforzar y ampliar el riego en la parte inferior de la huerta. De esta forma, la incorporación de un nuevo e importante caudal a la acequia Mayor permitió en la primera mitad del siglo XV prolongar dicha acequia a partir de San Juan (51) y trazar dos nuevos brazales desde este lugar: los de Alfadramí y la Moleta. Con esta obra se transformaba el hasta entonces secano de la parte inferior del alfoz alicantino en la llamada "huerta de Baix", por donde según Bendicho se extendía la viña. La definitiva extensión del espacio regado, con la creación de nuevos brazales en la margen izquierda de la acequia Mayor-Brazales de la Cruz, Murteretes o del Salt- y en la parte más baja de la huerta - de San Roque o de Canicia, entre otros- sólo podría acometerse con la construcción del pantano de Tibi.

Volviendo a nuestro documento, no deja de ser significativo que entre las disposiciones acordadas por el gobernador Nicolau de Pròxida destaquen aquéllas tendentes a evitar que la construcción de un nuevo azud vaya en detrimento de la antigua obra, insistiéndose en que se tomen toda suerte de medidas que aseguren el mantenimiento y reparación del azud y acequia viejos. De esto último se ocuparía el sobrecequiero, quien nombraría, según la costumbre de la villa, a un grupo de vecinos cuya misión sería la de mantener en condiciones la albarda del azud antiguo, bajo pena de cinco sueldos cada vez que contradijesen dicho mandato a exigir por el justicia ciudadano en nombre del rey (52); pena que de igual modo afectaría a dichos oficiales en caso de actuar de modo negligente o remiso en lo tocante a la conservación de esa obra. Finalmente señala el gobernador que en caso de que esta construcción nueva dañase los intereses de algún huertano, éste vería satisfecho dicho quebranto si la comisión integrada por "quatre bons hòmens" elegidos por aquél así lo considerase. Y condena a que quienes deliberadamente dañen el azud y la acequia viejos pierdan el puño derecho y paguen una multa de cien morabatinos de oro.

El azud nuevo y la acequia del Gualeró, con el ensanche posterior de los brazales de Alfadramí y La Moleta, supusieron sin duda la primera transformación importante del primitivo espacio regado islámico. Desde este momento, la historia de la huerta será la historia de las sucesivas ampliaciones del riego y la historia de los enfrentamientos entre los vecinos de la cabecera del río Montnegre y los de la huerta de Alicante por el derecho del agua. Sabemos que en 1640 ya debía haberse diseñado un nuevo 
brazal en la margen izquierda --el del Salt- y que después de esa fecha se irá ocupando la parte más baja de la fértil vega, llegando el riego en el siglo XVIII hasta la Condomina.

La huerla alcanzó su máxima extensión en las primeras décadas del siglo XX. Desde entonces la historia sigue un discurso inverso: aquello que fue lenta creación es ahora paulatina destrucción. 


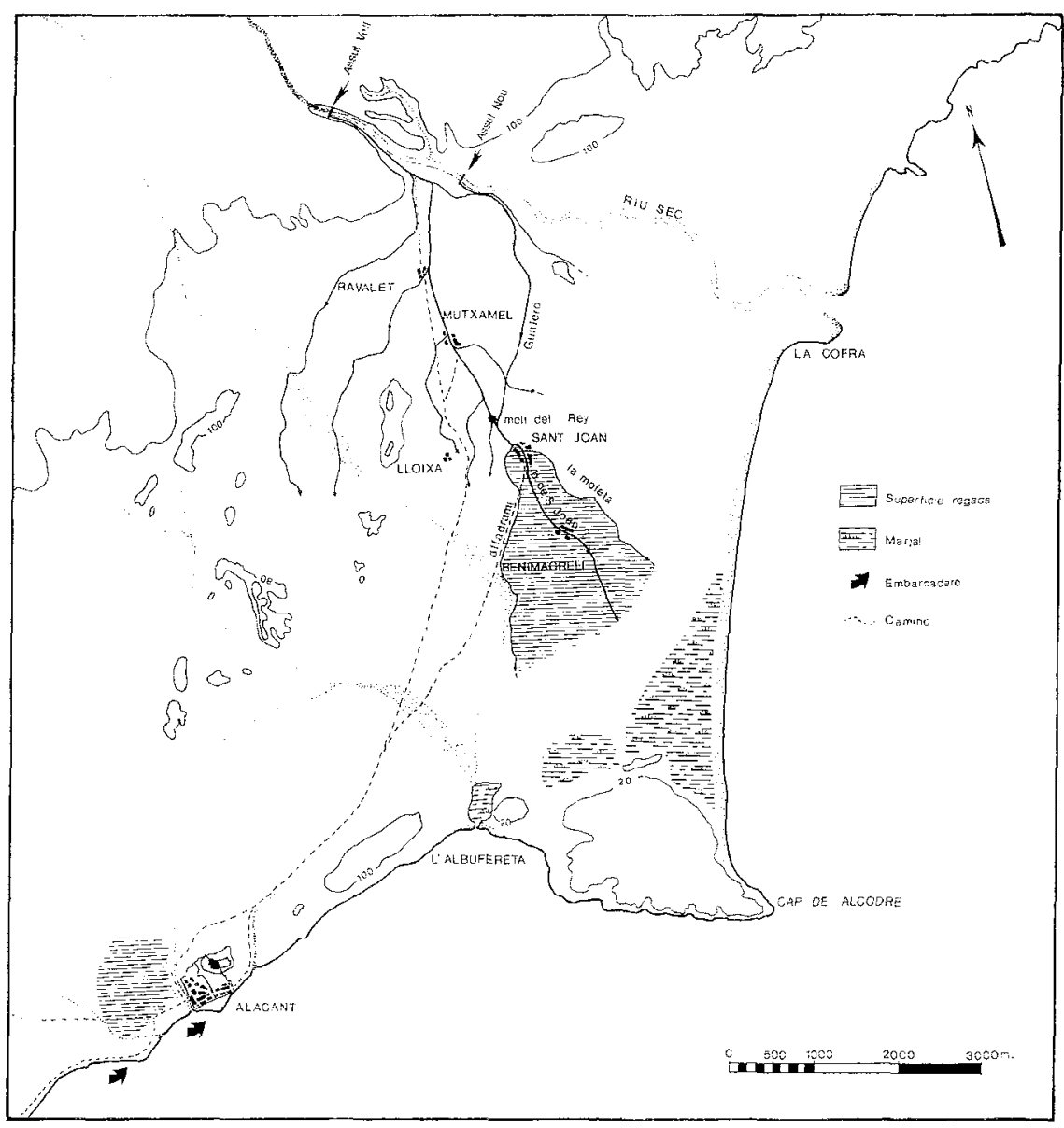

La huerta de Alicante en épaca bajomedieval. Trazada de la acequia nueva del Gualeró desde el Azud Nou y posible crecimiento posterior de la red de riego. 



\section{APÉNDICE DOCUMENTAL}

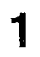

1369, agosto, 1. Valencia.

Pedro IV, a súplica de los herederos de Pere Celler, quien reivindicaban la posesión de unos hilos de agua en la huerta de Alicante, ordena a Nicolau de Pròxida, gobernador dellà Sexona, que recabe información y en caso de resultar cierta dicha reivindicación devuelva esos hilos a los suplicantes.

ACA, C, reg. 744, ff. $61 \mathrm{v}-62$ r.

En Pere, et cetera, al noble e amat conseller nostre En Nicholau de Pròxida, cavaller e governador de regne de València de Sexona enllà, o a son lochtinent, salutem et dileccionem.

Per part dels fills e hereus d'En Pere Celler, menor de dies, vehín de la vila d'Alaquant, quondam, e succehidors ab intestat d'En Pere Celler, maior de dies, vehín de la dita vila, avi lur, quondam, és estat en nostra Audiència clamat, demos. trat que jassia lo dit En Pere Celler, menor de dies, per entrega a aquell feta per la cort de la dita vila de un fil d'aygua que fon d'En Francesch de Puigmoltó, possehís lo dit fil d'aygua per algun temps, és a saber, del dia de la dita entrega tro al dia que la dita vila fon per lo rey de Castella, quondam, o per companyes sues per occasió de la guerra que era entre nos e aquell derrerament occupada. Jassia encara lo dit En Pere Celler, maior de dies, per títol de venda, la qual li fon feta per lo amat conseller e tresorer nostre En Ramon de Vilanova axí com a comissari per nos assignat a occupar e vendre en nom nostre e per nos tots e qualssevol béns que en la dita vila e terme d'Alaquant fossen ladonchs atrobats de persones qualsevol habitants en la terra del dit rey, possehís en la orta d'Alaquant dos fils d'aygua, los quals eren estats de Anthoni Ginestar, vehí de la dita vila, qui durant la dita guerra era e estava en Castella e s'entremetia dels actes o affers de la dita guerra contra nós. Emperò, segons se diu, per ço, car en la dita destrucció lo libre nou de la partició de les aygües de la orta de la dita vila, en lo qual eren escrits los noms de aquells qui justa-// ment $e$ ab justs títols possehïen los fils de les dites aygües, fon perdut, no solament tota la aygua de la dita orta del temps de la dita destrucció ençà és estada regida e partida e a present se regeix, e.s parteix ab lo libre antich, 
ans encara los dits fils d'aygua als dits pubils pertanyents són estats occupats e possehïts, e.s posseeixen de present per algunes persones no havents algun dret en aquells, per la qual raó los dits pubils han perdut e perden injustament e no deguda ço que ab justs títols e segons lo dit libre nou los pertanya e pertànyer podia e devia en los tres fils de aygua dessús dits. Perquè a humil supplicació per aquesta raó a nos feta, a vós dehim, comanam e manam que reebuda per vos informació sumària sens pleyt e sens solempnitat judicial de les dites coses, si atrobarets aquelles ésser veres, façats tornar encontinent e de fet als dits pubils e a cascun d'ells toł ço que trobarets que.ls pertanga en los dits fils d'aygua, remoguts altres qualssevols il.lícits e injusts possehidors o detenidors d'aquells, procehint en les dites coses segons que de fur e rahó atrobarets ésser faedor, solament la veritat del fet attesa, qualsevol malícies e difugis foragitats. En tal manera, sobre les dites coses vos havent que los uns no tinguen ne posseesquen injustament ço que als altres pertany, majorment béns o coses de pubills e de persones qui aquells béns per títol de compra de nos o de nostres comissaris feyta poden e deven justament possehir. Nós, emperò, sobre les dites coses e devallants o anexes de aquelles comanam a vós nostres veus plenerament ab la present.

Dada en València, primer dia del mes d'agost, en l'any de la nativitat de nostre Senyor M CCC LX IX. Guillermus de Palou.

Petrus Vitalis, ex peticione provisa in Audiencia per Marchum de Turribus, iurisperitum et auditorem.

\section{2}

1377, junio, 21. Alicante.

Capítulos para la construcción de un azud y de una acequia en la huerta de Alicante.

AMA, Armario 16, caja $1, n^{\circ} 11$.

Anno a nativitate Domini millesimo trescentesimo septuagesimo septimo. Comparech denant la presència del molt noble mossèn En Nicolau de Pròxida, cavaller e conseller del molt alt senyor rey e portantveus de governador en Oriola en part del regne de València deçà Xexona, En Pere de Peralta, / vehí de la vila de Alacant, e presentà al dit noble, e per mi, Guillem Cavaller, notari publich per auctoritat reyal per tota la terra e senyoria del molt alt senyor rey, legir e publicar féu una carta de comissió del molt alt senyor rey en paper scrita e ell dos de aquella sagellada ab lo sagell / secret del dit senyor empremtat en cera vermella, la qual és de la tenor següent:

Petrus, Dei gracia rex Aragonum, Valencie, Maioricarum, Sardinie et Corsice comesque Barchinone, Rossilionis et Ceritanie, nobili et dilecto consiliario nostro Nicolao de Proxida, militi, gubernatori Oriole, salutem et / dileccionem. Expositum fuit nobis humiliter pro parte aliquorum habitatorum ville Alicantis habencium possessiones in orta dicte ville, quod aliqui qui partem habent in aqua cequie labentis 
per terminum dicte ville maliciose contradicunt quod non fiat inibi acutus et cequiam per infantem Ferdinandum dudum intra / jpsum terminum fieri ordinatos ob quod rej publice dicte ville magna incomoda subsequntur, nam ex aqua que posset decurrere per dictos acutum et cequiam queque decurit ad marem et nulum fructum afert sine detioratione cequie veteris possint regari plurime ex possessionibus dicte orte et / per consequens personis in dicta villa degentibus magna comoda provenirent. Qua propter, suplicato nobis eis super hiis de oportuno remedio provideri, vobis di. cimus, comittimus et mandamus quatinus, vocato ad hec si vobis videatur baiulo generali regni Valencie ultra Sexonam ac vocatis evocandis, si / repereritis dictum acutum et cequiam fore necessarios, bonos et utiles rei publice dicte ville illos con. festim fieri faciatis, compellendo illos qui ex aqua dictorum açuti et cequie comodum reportare debent quod per viam talii, imposicionum vel alium quem vobis videbitur acutum et cequiam faciant / suppradictos. Et super hiis difugium, appellacionem, dilacionem aut excepcionem nullatenus admittatis, cum nos attento quod comodum rei publice preponendum est private sic fieri velimus de certa sciencia et consulte. Comittentes vobis super predictis omnibus et singulis et dependentibus seu emergentibus / ex eisdem vices nostras plenarie cum presenti.

Data Barchinone, sub nostro sigillo secreto, XXII die octobris, anno a nativitate Domini $\mathrm{M}^{\circ} \mathrm{CCC}^{\circ}$ septuagesimo sexto. Rex Petrus.

Et presentada la damunt dita carta de comissió e aquella davant lo dit noble governador per mi, dit notari, legida e publicada, dix que / reebia aquella ab deguda e homil reverència, e que appel.lats aquells que.y fahien appel.lar que era prest $e$ aparellat de enseguir e complir tot ço que en la dita carta de comissió era contengut e de fer hic justícia segons que per fur e bona rahó atrobaria ésser fahedor.

Post hec vero, die dominica, qua com-/ putabatur VII ${ }^{a}$ iunii, anno predicto a nati-

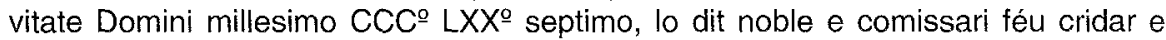
manà ésser cridat consell general en la dita vila, lo qual fon cridat ab trompeta per Gonçalbo Martíneç, corredor e carceller de la dita vila, segons qui és acostumat cridar o publicar altres consells / generals. Et cridat lo dit consell per la forma damunt dita encontinent les dues parts e més dels vehïns de la dita vila foren e anaren a una esgleya appel.lada Sent Nicolau, parròquia de la dita vila, e lo dit noble e comissari hoy a cascú dels lurs rahons e al-legacions, e fos acordat per la major partida / de aquells del consell que de continent e de feyt trametessen per un bon maestre livelador d'aygües que la obra del dit açut veés e regonegués per tal que.ll dit noble e comissari pogués mils deliberar sobre la dita obra. Et a poch instant del dit dia fon manat a mi, dit notari e scrivà del present feyt / per lo dit noble e comissari, que anàs a la ciutat de Xàtiva e que hagués lo milor maestre que y fos de livelar aygües, e yo, dit notari, acceptat lo dit manament del dit noble e comissari, lo diluns següent partí de la dita vila e aní a la ciutat de Xàtiva per la dita rahó. Et estat en / la dita ciutat de Xàtiva per lo honrat En Berenguer de Valfior, savi en dret, assessor del dit noble e comissari, e per mi, dit notari e scrivà del present feyt, fon demanat a molts de la dita ciutat qui era lo milor maestre de livelar aygües en la dita ciutat, e per tots comunament fon respost / que no y havia tan bon maestre com En Juhan Garcia, ciutadà de la dita ciutat, e de continent fon parlat per lo dit En Berenguer de Valfior e per mi, dit notari, ab lo dit En Juhan Garcia e fon finat de preu ab ell ena. prés vench-se'n ab mi ensemps a la dita vila de Alacant. 
Post hec vero, die dominica, / qua computabatur XIIII die iunii, anno predicto a nativitate Domini $\mathrm{M}^{\circ} \mathrm{CCC}^{\circ}$ septuagesimo septimo, instant e requirent los damunt dits prohòmens ço és la maior part de la vila, requerín al dit noble e comissari que pus lo maestre era vengut que anàs a veure ensemps ab lo dit maestre per regonèyer la dita / obra de açut on ni en qual loch del dit baranch seria milor a profit del senyor rey e a població de la dita vila. Et lo dit noble e comissari, vehent la dita requesta ésser justa e consonant a rahó de continent, anà ensemps ab lo dit maestre e ab la major partida dels prohòmens de la dita vila, ço és / justícia e jurats e molts altres anaren a la orta de la dita vila e plegaren al barranch on lo dit açut se devia fer, e aquí la dita obra fon vista a huyll per lo dit noble e comissari e per lo maestre e tots los altres justícia e jurats e prohòmens de la dita vila. Et no-res-menys lo dit noble e comis-/ sari per justificar lo dit feyt encontinent reebé sagrament del dit maestre, lo qual jurà per Déu e pells sants Quatre Evangelis de aquell que ell no y diria res per temor ni per neguna altra enganosa manera, ans diria veritat de tot son enteniment. Et reebut lo dit sagrament del dit maestre encon-/ tinent lo dit comissari interrogà al dit maestre on ni en qual loch del dit barranch estaria milor lo dit açut a profit e utilitat del dit senyor rey e a població de la dita vila, lo qual respòs e dix, sots virtut del dit sagrament, que lo milor e pus abte o profitós loch per a fer lo dit açut era un loch on / ha tres tormos de rocha, en lo loch appel.lat lo Conxell, ço és, en lo dit barranch contengut en la dita carta de comissió; fon interrogat, sots virtut del dit sagrament, perquè més en aquell loch que en los altres, e dix que per ço com lo açut era alí pus ferm en tant com hic havia / rocha e lo dit açut seria alí pus ferm e pus durable. Et en aquell instant mateix lo dit noble e comissari per justificar mils la fahena interrogà a alcuns prohòmens antichs de la dita vila, ço és Berenguer Gironès e En Francesch d'Artés, En Berenguer Lofriu e An Juhan Lario, los quals / se dehia que y eren estats ja en lo temps que lo infant En Ferrando volia fer lo dit açut, los quals, sots virtut de sagrament, respongueren cascú per si e tots en una concordantment que lo dit infant en aquell temps manà ésser fet lo dit açut en to dit loch, ço és alí on són los dits tres / tormons de rocha en lo dit loch appel.lat lo Conxell. Et a superabundant cautela lo dit noble e comissari, per la concordança dels dits testimonis oc i encara per ço que.l dit maestre havia dit, manà al dit maestre que romangués alí e de continent tornàs a livelar on e en qual loch de la dita / orta poria mils exir la dita aygua, al qual foren donats per acompanyats a aquell En Francesch Pasqual, En Jachme d'Olit, En Juhan Bevià, En Pere Peraita, Juhan Lario, vehïns de la dita vila. Et no-res-menys, en aquell instant mateix En Francesch Pasqual, vehí de la dita vila, dix e de paraula / protestà que en cas que la feta del dit açut fos contra ell ni.l preiudicàs en neguna cosa que protestava que tot son dret li romangués salvu e illè̀s e que o pogués demanar tota hora que ben vist li fos, e requeri a mi, dit notari e scrivà del present feyt, ésser feta carta pública a conservació / de son dret e per haver memòria en esdevenidor. Et no-res-menys demanà translat de la dita carta de comissió, lo qual per lo dit noble e comissari li fon manat donar e deliurar, e manà a mi, dit notari, que de continent li'n donàs translat.

Post hec vero, die veneris, vicesima die / iunii, anno a nativitate Domini millesimo trescentesimo septuagesimo septimo, vengueren lo dit En Juhan Garcia, maestre del livelar lo dit açut e cèquia de aquell devalant, e los dits prohòmens, los quals 
li foren donats per acompanyats a la livelació del dit açut e cèquia, e recomptaren e relació / feren de la dita hobra per capítols per ells fets en la forma següent:

En nom de Déu sia e de madona Sancta Maria, comença a livelar en Juhan Garcia, vehí de Xàtiva e maestre de la dita hobra, diluns, a XV dies de juny, del any damunt scrit mill CCC LXXVII, ço és saber lo açut / nou del qual és comissari lo noble mossèn En Nicolau de Pròxida, cavaller e conseller del senyor rey e governador en partida de regne de València deçà Xexona, lo qual livell és e va per la manera deiús següent:

Primerament, atroba lo dit En Juhan Garcia pus alt lo banchal / davant lo açut on l'aygua deu engravar que no és lo tormo qui és del açut XVI palms.

Ítem, anant avant ab lo livell en lo banchal davant lo corrall de Na Granulesa, atroba lo dit maestre que era egual ab lo tormo del açut, lo qual és fitat.

Ítem, anant / avant en lo dit banchal, pujant avant al corral troba lo dit maestre que era egual ab lo banchal on lo açut començarà de engravar.

Ítem, anant avant ves lo banchal daval lo banchal del Conxell envés lo riu fa afondar IIII palms e és senyalat d'una creu.

ítem, puiant als / banchals dels hereus d'En Bonanat Martí és fitat e fa afondar XXXV palms.

Ítem, en lo banchal avant, on ha una fita, fa afondar XXXV palms, e són dues tafulles de larch e VII passes, e és prou fonda.

Ítem, al altre banchal anant envés lo riu fa afondar XVII palms, e / és fitat, e és prou fonda, trossús a un garrofer que y ha, e és fitat davall lo corrall.

Ítem, fa afondar en lo colado daval lo coral d'En Bonanat Martí, anant devés la vinya de $\mathrm{Na}$ Granulesa, e tí de larch tafula e miga, e fa afondar XXXVII palms, e és la cèquia prou fonda.

Ítem, / partint del banchall passat lo collado avant envés la vinya de Na Granulesa e la foya d'En Bonafonat al cap d'amunt de la vinya fa afondar X palms, e és prou fonda la cèquia.

Ítem, anant avant aprés de la vinya de $\mathrm{Na}$ Granulesa tro al partidor de Benytia, fa afondar XV palms a la entrada / e V palms ves lo partidor.

Ítem, partint de la vinya del partidor de Benitia, anant dessús lo banchal del Conxell, passant per la vinya de Na Johaneta e passant per la heretat de Na Ruberta tro als mores, ha prou que s'afonde de VII a VIII palms.

Ítem, partint dels dits mores, devalant / per la terra d'En Nicolau Amat, XVI palms, e té tafula e miga.

Ítem, anant per la foya d'En Vidal Gómez, passant per davall lo cantó de la vinya vela, entrant en lo banchal de Nicolau Amat, sensal d'En Durà, fa afondar VI o VII palms.

Ítem, partint del dit banchal, passant pel plan-/ ter d'En Vidal Gómez, tro a la vinya d'En Durà, fa afondar VI o VII palms.

Ítem, partint de la dita vinya d'En Durà, passa per la terra d'En Rochafort fins al molí del rey de part daval e tro a la cèquia, fa afondar VI o VII palms, e tots los dits 
lochs d'aquí amunt són tots fitats, / e dóna en la cèquia major de loch en loch, e passa daval lo dit molí, e passa per un banchal del Franquet, e dóna en la cèquia.

Et feta la damunt dita relació per los damunt dits maestres e acompanyats encontinent lo damunt dit noble governador e comissari, a instància e requisició / dels sobredits prohòmens e per son propri motiu per justificar son fet, féu cridar consell públich en la dita vila, segons qui és acostumat, per al dichmenge avant qui serà comtat XXI dia de juny. Et no-res-menys acordà la sentència en la forma següent:

Nós, En Nicolau de Pròxida, cavaller e conseler / del molt alt senyor rey e portantveus de governador en part del regne de València deçà Xexona, e jutge e comissari a les cosses dessús scrites assignat per lo molt alt senyor rey, vista una comissió del molt alt senyor rey per En Pere de Peralta, vehí de la dita vila de Alacant a nós presentada; / vist enaprés tot lo poder en la dita comissió del dit senyor rey a nós atribuït e donat; vist enaprés com la dita carta de comissió fon per nos reebuda ab deguda reverència e honor; vist enaprés lo consell general, lo qual fon tengut en la dita vila die dominica, que era comptat VII die / iunii, anno preinserto; vist enaprés tot ço que fon acordat en lo dit consell, ço és que fos tramés a un maestre que fos abte de livelar lo dit açut e cèquia e com fon haüt per abte e per suficient de livelar lo dit açut e cèquia En Juhan Garcia, ciutadà de Xàtiva, a mercè de la dita hobra; / vist subsequenter la requesta que fon feta per los dessús dits / prohòmens XIIII ${ }^{a}$ die iunii, anno presenti et infrascripto; vist encara com en aquell dia mateix fon vista a huyll per nós e per la major part dels prohòmens de la dita vila e per lo dit maestre la hobra del dit açut; vist iterum lo sagrament / que.ll, dit maestre, féu en poder nostre de conselar dret e veritat, e la resposta per ell feta; vista encara la resposta del dit maestre on ni en qual loch estaria milor lo dit açut a servir del senyor rey e a profit e utilitat e a població de la dita vila; vist enaprés la interrogació per nós feta A.n Berenguer Gironès e A.n Francesch d'Artés / e A.n Berenguer Lofriu e A.n Juhan Lario, los quals dehien que y eren estats ja en lo temps del infant Don Ferrando; vist la resposta sots virtut de sagrament per ells feta; vist enaprés com per nós foren donats per acompanyats al dit maestre per a livelar lo dit açut e cèquia En Francesch Pasqual, En Jachme d'Olit, / En Juhan Bevià, En Pere Peralta, Juhan Lario, vehïns de la dita vila; vist enaprés la protestació, la qual lo dit En Francesch Pasqual féu e requerí carta pública; vist enaprés com per nós li fon atorgat translat de la dita comissió; vist enaprés la relació per lo dit maestre e acompanyats per ells a nós feta $X X^{a}$ die iunii, / anno predeclarato, per capítols per ells ordenats; vist enaprés tots los capítols de la dita relació per ells feta de primo capitulo usque ad ultimum; vist tot ço e qualsevula cosa que en lo dit procés o enantament fahia a veure e tot ço àls que en lo dit feyt a veure e regonèxer fahia, Deus havent, denant nostres / huylls e los sants Quatre Evangelis de aquell denant nos posats, per ço que per reverència e temor de aquells mils siam inclinats en to dit feyt fer justícia e egualtat, seents pro tribunali en loch abte e covinent de jutgar, haüt acord e delibaració en e sobre lo dit fet ab e de consell del dit En / Juhan Garcia, maestre damunt dit de la dita hobra de açut e cèquia, enantam a promulgar sentència en lo dit feyt en la forma següent:

Com a nós sia cert fer lo dit açut e cèquia ésser servir del senyor rey e necessaris, bons e profitosos a la cosa pública de la dita vila. Et açò per la major part dels habitants en / aquella oc encara per lo dit En Juhan Garcia, maestre, appel.lat e demanat a la dita hobra; per tal, pronumciam, jutgam e declaram lo dit açut ésser 
fet en lo riu [ ] (54), per lo qual e per la qual les aygües escampants del açut antiga decorren a la mar, ço és daval lo barranch appel-\{at de Matilarany en lo loch / on ha tres tormos o cantalls de rocha qui és en dret del partidor appel.lat lo Conxell e engrave l'aygua del dit açut primerament en lo banchal de terra qui és davant lo dit açut, e és d'En Berenguer Durà, ciutadà de València, e seguint la dita cèquia vaia per lo banchal davant lo coral de Na Granulesa, e seguint / encara avant la dita cèquia ha a passar per lo banchal daval lo braçal del Conxell envés lo riu. Et enaprés ha a pujar als banchalls dels hereus d'En Bonanat Martí e ix a un garrofer que és daval lo corrall d'En Bonanat Martí, anant ves la vinya de Na Granulesa on ha un colado, e passat / lo dit collado va ves la vinya de la dita Na Granulesa e la foya d'En Bonafonat de Vallebrera al cap d'amunt de la vinya e va a ferir al partidor de Benitia, e del dit partidor, passant lo braçal del Conxell, ha a passar per la vinya que fon dels hereus del dit En Bonanat Martí e per la heretat que fon d'En / Bernat Rubert tro als mores, e dels dits mores a a passar per la heretat d'En Nicolau Amat a la part d'amunt e per la foya d'En Vidal Gómez, e vé al canto de la vinya vela del dit En Vidal, entrant en lo banchal d'En Nicolau Amat, sensal d'En Francesch Durà, e de la dita vinya a passar per la terra d'En Guillem de / Rochafort e vé a un banchal d'En Jachme Franch, e depuys vé al moli appel.lat del senyor rey a la part d'aval, e de aquí engrava en la cèquia Major de la dita orta, en e segons per lo dit En Juhan Garcia, maestre de la dita hobra, e acompanyats de aquell és estat fitat e senyalat. Encara, pro-/ nunciam e declaram lo dit açut e cèquia deure ésser fet e obrat ab acabament dels diners que.s han cascun any de les imposicions que.s culen, e.s leven en la dita vila, és saber, que sien diputats e assignats de les dites imposicions a fer la dita hobra per cascun any quatre mille solidos tro e / tant que la dita açut e cèquia sia acabada. Retenim, emperò, a nós que fahent e continuant la dita hobra, si ben vist nós serà, puxam taxar o fer taxa e ordenar entre los profitants e ajudants-se de la dita açut e cèquia tala o tales perquè la dita hobra puxa venir breument a acabament. / Et axí mateix que sien donats e assignats a la dita hobra tots e qualsevulla deutes o quantitats degudes al dit Consell tro al present dia de huy. Encara, pronunciam e declaram que les dites aygües que per lo dit açut e cèquia decoreran sien e puxen ésser partides a coneguda del dit En Juhan / Garcia, maestre, o de altres maestres ab aquells capítols, ordenacions e provisions per nós e per aquell o aquells fahedores e ordenadores ab imposicions de penes o en altra manera per exsecució de aquelles. Encara, pronunciam e deciaram que per ço com és temor que per la present e nova açut e cèquia l'açut (55) / e cèquia antiga no reeba deteriorament o pigorament, que encontinent que les aygüesduyts e esdeveniments derocaran o deruiran la albarda, la cèquia e tot ço que necessari hic sia de la dita açut antiga, lo sotscequier, qui ara és o per temps serà, mane e haja a manar, segons forma acostuma-/ da, los habitants en la dita orta que vaien e pugen a adobar e tornar la dita albarda en la dita açut antiga, e si aquells e qui serà manat per lo dit sotscequier contradiran o cessaran de pujar e anar, tornar la dita albarda en la dita açut antiga que sien cayguts e encorreguts en pena / de XX solidos per cascuna vegada que contrafaran de lurs béns tota la dita pena aplicadora e guanyadora als cófrens del dit senyor rey, e que lo dit sotscequier, qui ara és o per temps serà, sots virtut del sagrament per ell fet e fahedor ell començament de la sua elecció, sia tengut de notificar e nome-/ nar al justícia de la dita vila, qui ara és o per temps serà, los noms de aquell o aquells qui cessaran o contradiran a anar a 
adobar la dita albarda de la dita açut antiga. E lo dit justícia sia tengut encontinent e de feyt totes excepcions e defenssions e dilacions a part posades, exigir e levar a obs dels cófrens del dit senyor / rey de aquell $O$ aquells qui nomenats e notificats li seran la damunt dita pena. Et si lo dit sotscequier cessarà de nomenar o notificar aquells al dit justícia que sie encorregut e caygut en la dita pena de e per aytants com cessarà de nomenar o notificar, la qual lo dit justícia sia tengut de exigir e / levar en la forma damunt dita. Et si lo dit justícia serà necligent o remis en exigir e levar les dites penes, en aquest cas sie a elecció de nos o del governador, qui per temps serà, de exigir e levar les dites penes del dit justícia o de aquells qui seran encorreguts e cayguts en aquelles ensemps ab tots los dans, / messions e interesses que per la dita rahó se covendrà fer e sostenir. Et no-res-menys lo dit sotscequier logue e puxa logar hòmens qui tornen la dita albarda en lo dit açut, los quals encontinent semblantment sien satisfets e pagats del salari o loguer que aquell los prometrà per los contradients o / cessants (56) anar a la dita açut com los serà manat. Et axí mateix, la dita açut antiga e cèquia sia tenguda e conservada en son estament en manera que no puxa venir a deruïment o pijorament, axí de les imposicions de la dita vila com de tala comunament imposadora o taxadora entre los habitants en la dita / vila o en la forma e manera que antigament és estat acostumat tenir e conservar la dita açut e cèquia en condret. Et axí mateix, nos reservam, e.ns retenim que tota hora que a nos ben vist serà puxam corregir e esmenar la dita sentència a consell de dos savis o de aquells que a nos ben vist serà / per capítols o per altres ordenacions no mudant la sustància de la present sentència a servir del dit senyor rey e a profit e utilitat dels habitants en la dita vila, los quals capítols e ordenacions sien tengudes e observades e hajen aquella fermetat e valor que haurien si en la present sentència de present eren / scrites e ordenades, e axí ara com ladonchs e ladonchs com ara eren ací scrites e ordenades. Encara, pronunciam e declaram que per tots e qualssevulla lochs per on la dita cèquia passarà e farà dan a alcú en sa possessió que aquell dan sia satisfet e pagat a aquell qui.l dan sostendrà, a conexença / de quatre bons hòmens per nós elegidors. Encara, pronunciam e declaram per esquivar bregues e baralles e daguen que se. $n$ porien seguir morts o nafres 0 altres scàndells e perills que si alcú de certa sciència o en altra manera deruiran o deroquaran en temps de les aygüesduyts vel àlias la dessús dita / albarda del açut antiga que aquell o aquells qui açò faran o asaiaran perden lo puny dret sens tot remey, e no-res-menys sien encorreguts en pena de cent morabatins d'or applicadors de lurs béns al cófrens del senyor rey. Lata sentència per lo dit jutge e comissari en la dita vila de / Alacant presents tots los sobrenomenats e de volentat e exprés consentiment de aquells vicesima prima die iunii, anno a nativitate Domini millesimo trescentesimo septuagesimo septimo.

Se (signo) nyal del noble En Nicolau de Pròxida, jutge e comissari sobredit, qui la dita sentència dóna e promulga. Foren presents / a la dació e prolació de la dita sentència En Bonaffonat de Vallebrera, justícia, En Guillem Çalort e Francesch Pasqual en nom de jurats de la dita vila e tota la major partida dels prohòmens de la dita vila, los quals tots ensemps e cascú per si en los dits noms e en lurs noms propris loaren e aprovaren, / ratificaren e confermaren la damunt dita sentència.

Presents testimonis foren a les damunt dites coses lo honrat En Lop Eximeneç de Peranxiza e En Garcia de Verdú [ ] (57) del senyor rey e En Sanxo de Conqua e Ferran Martíneç de la Gonella, habitants en la dita vila. / 
Et en aquell instant mateix lo dit En Francesch Pasqual, en son nom propri, encontinent protestà oc encara axí com a jurat que en cas que la dita sentència fos donada en preiudici seu o de alcun altre que no.y consentia e pogués recórrer al senyor rey o a qui.s pertangués e que temps per la dita rahó no li corre-/ gués. Et lo dit noble, jutge e comissari dix que lo us salvava en tant com de fur e de rahó salvar lo.y podia e no en pus. Et no-res-menys, en aquell instant mateix los dits honrats justícia e jurats e prohòmens de la dita vila, perquè la dita hobra vingués a perfecció, donaren plen poder al dit / noble e comissari que pogués elegir aquell o aquells qui ell volgués per obrers de la dita hobra de açut o fer lo dit açut per via de encant ab consell dels dits justícia e jurats. E de continent eodem die et anno ora vesperorum vel quasi lo dit noble e comissari elegí en obrés del dit / açut los sobredits En Guillem Çalort, jurat, e En Jachme d'Olit, als quals donà plen poder que poguessen fer la dita hobra e constrènyer e forçar tots aquells que deguessen alcuns deutes a la dita vila, ço és a saber, aquells que foren assignats a la dita hobra de açut en / pagar les quantitats per ell degudes e fer la dita hobra per manera que vingués a acabament com abans poguessen, los qual juraren en poder de mi, notari e scrivà del present feyt, stipulant e reebent en loch de aquells de qui.s pertanya per Déu e per los sants Quatre Evangelis / per les mans dels sobredits corporalment tocats que ells se haurien bé e leyalment en la dita hobra de açut e en la administració de aquell. Et no-res-menys lo dit noble e comissari corregí e esmenà la sua sentència la on diu que aquells a qui sera manat per lo dit / sotscequier contradiran o cessaran de pujar, anar e tornar la dita albarda en la dita açut antiga que sien cayguts e encorreguts en pena de vint solidos, no sien sinó cinch solidos, totes les altres dites coses de la dita sentència romanents en sa força e valor. I

Sig (signo) num mei, Guillermi Cavaller, regia auctoritate notari publici Valencie et per totam etiam aliam terram et dominacionem illustrissimi principis et domini nostri regis Aragonum, qui predictis interfui eaque scripsi cum raso et emendato in $\mathrm{XV}^{\mathrm{a}}$ linea / ubi liquet ciutat-, et cum raso et emendato in eadem linea ubi patesit .feyt., et etiam cum raso et emendato in prima linea processus qui fuit factus post sentenciam qui incipit . Et en aquell instant. ubi aptatur rahó no li corre., et clausi loco die et anno prefixo. 


\section{NOTAS}

(1) MARTÍNEZ MORELLÁ, V. Pivilegios y Franquezas de Altonso $x$ el Sabio a Alicante, Alicante, 1951, n 12, p. 22

(2) También conocido por riu de Cabanes o riu Vert y más recientemente riu Sec.

(3) CABEZUELO PLIEGO, J.V. La guerra de los dos Pedros en las tierras alicantinas, Alicante, 1991.

(4) El origen, desarrollo e impacto de la guerra de los dos Pedros en el sur del reino de Valencia ha sido tratado recientemente por J. V. Cabezuelo, ibidem, siendo igualmente interesantes los estudios de M. a T. Ferrer, "Causes i antecedents de la guerra dels dos Peres", Boletín de la Sociedad Castellonense de Cultura, LXIII, Castellón, 1987, pp. 445-508, y "La frontera meridional valenciana durant la guerra amb Castella dita dels dos Peres", Pere el Cerimoniós i la seva època, Barcelona, 1989, pp. 245-357. Sobre otros aspectos de la huerta de Alicante en la Edad Moderna resultan de especial interés los trabajos de A. Alberola, El pantano de Tibi y el sistema de riegos de la huerta, Alicante, 1984; ibídem, Jurisdicción y propiedad de la tierra de Alicante (siglos XVII y XVIII), Alicante, 1984; ibidem, "Agricultores y monopolistas: el control del agua de riego en las comarcas meridionales del País Valenciano durante la Edad Moderna", Agua y modo de producción, Barcelona, 1990, pp. 188-211; ibidem, Datos para la ordenación del territorio en la cuenca del río Montnegre, en prensa. Gentileza del autor.

(5) El estudio de la huerta desde una perspectiva arqueológica ha sido abordado por S. Gutiérrez, "La huerta medieval. Los sistemas de riego", Tibi, un panta. no singular, Valencia, 1989; ibidem, "La huerta y el alfoz". Historia de la ciudad de Alicante, Alicante, 1990, pp. 15/-176.

(6) GUTIÉRREZ LLORET, S. "La huerta y el alfoz ..."

(7) MARTÍNEZ MORELLÁ, V́, op. cit., no 9, p. 20.

(8) El mantenimiento de las normativas de época islámica es patente er los casos de Orihuela y Elche: el privilegio expedido por Alfonso $\mathrm{K}$ el 14 de mayo de 1275 en Valladolid señala que en la huerta de Orihuela se "... guien las aguas en tal manera que rieguen e lieguen tanto como solian en tiempo de moros et mas si pudieren, (...) et que las guien por aquellos lugares que solian yr en tiempo de moros, et que fagan que todas las tierras se rieguen por las paradas do solian tomar su tanda en tiempo de moros et non en otro lugar. (...) Et las paradas se fagan como en tiempo de moros et non de otra manera,...". TORRES FONTES, J. Colección de Documentos para la historia del Rei- 
no de Murcia. III.- Fueros y privilegios de Alfonso $X$ el Sabio al reino de Murcia, Murcia, 1979, pp. 149-150. El ejemplo de Elche procede de la confirmación de una partición de heredades realizada por el infante don Juan Manuel y señala "... que el agua con que se regavan las alcarias do son destas heredades, que las ayan assí como la solien aver los moros en el so tiempo". TORRES FONTES, J. Colección de Documentos para la historia del Reino de Murcia, II.- Documentos del siglo XIII, Murcia, 1969, p. 36.

(9) ALBEROLA ROMÁ, A. El pantano de Tibi ..., p. 29 y ss.

(10) VERGARA Y PARAVECINO, J.B. Manifiesto histórico legal de las especies, y adquisición del agua, que fluye a la vega de Alicante, por el río nombrado de Cavanes..., Alicante, 1739; y VERDÚ, F. Discurso sobre el dominio, pertenencia, distribución y uso de las aguas, que sirven al riego público la huerta de esta ilustre ciudad de Alicante, Alicante, 1739.

(11) En concreto, Juan Bautista Vergara y Paravecino, en un tratado de 1739 sobre el derecho de agua, afirma que el citado privilegio se encuentra en el Archivo Municipal de la Ciudad en "... la memoria de titulos sobre pertenencia de todas las aguas vivas, naturales y plùviales, que discurren por el rio de Castàlla de este territorio, Onil y Tibi, desde la conquista, para el riego de la huerta..." VERGARA Y PARAVECINO, J.B. op. cit., p. 5.

(12) GUTIÉRREZ LLORET, S. "La huerta y el alfoz ...", pp. 165-166.

(13) VERDÚ, F. op. cit., p. 31.

(14) Los argumentos que permiten sostener tal hipótesis, así como el método que posibilitó ir eliminando los espacios agrarios más modernos partiendo de la huerta del siglo XVII, fueron debidamente expuestos en un trabajo anterior, a cuya consulta remitimos para un análisis pormenorizado. Cf. GUTIÉRREZ LLORET, S. "La huerta y el alfoz ..."

(15) Acerca de la guerra con Castilla en estas comarcas cf. CABEZUELO PLIEGO, J.V. La Guerra de los dos Pedros ...

(16) "Item, senyors, que com los moros habitadors de la orta del dit loch lo temps passat fossen franchs de tota peyta de privilegi real atorgat per l'alt senyor rey En Jacme, que sia mercé de vos, senyors, que per bé e població de la orta e del dit loch, que sien franchs d'ací avant en per tots temps per fer-ne gràcia $e$ mercé al dit Consell ...". ACA, C, reg. 899, ff. 150v-151r.

(17) ZURITA, J. Anales de la Corona de Aragón, T. IV, edición preparada por Angel Canellas López, Zaragoza, 1973, L. IX, cap. VII, p. 314.

(18) LÓPEZ DE AYALA, P. "Crónica de don Pedro I de Castilla", Crónicas de los reyes de Castilla, Biblioteca de Autores Españoles, vol. LXVI, Madrid, 1953, p. 498.

(19) ACA, C, reg. 913, ff. 37v-38r. (1366, septiembre, 26). Cf. FERRER I MALLOL, M. ${ }^{-}$T. Les aljames sarraines de la Governació d'Oriola en el segle XIV, Barcelona, 1988, doc. 96.

(20) "... Com segons que per part dels prohòmens e universitat de la vila d'Alacant havem entés les més viandes que són necessàries en aquella hi hagen a ésser portades ab rècua d'altres diverses parts. E sia molt necessari que en la dita vila sia provehït de companyes a cavall que acompanyen la dita rècua, per tal manera que aquella puxa ésser deffesa als enemichs e sens perill continuar en portar les dites viandes, e encara altres coses necessàries als habitants de la dita vila, e que los dits habitants, e encara aquells qui en la dita vila seran assig- 
nats per frontalers proveïts de les coses a elis necessàries e specialment de les dites viandes, mellor puxen habitar e estar en la dita vila per guarda e deffensió d'aquella... per tal manera que aquells qui en la dita vila seran mellor puxen aturar en aquella e que no hagen a desemparar aquella per defalta de les dites viandes e de les altres coses que de necessitat hi deven de altres parts ésser aportades....". ACA, C, reg. 1388, f. 146r-v. (1367, mayo, 8).

(21) Fenómeno este de destrucción de acequias que parece que igualmente se produjo en el cercano valle de Elda durante la guerra con Castilla. Esta puede ser la razón por la que Pedro el Ceremonioso, en 1367, condona a la aljama sarracena eldense las rentas señoriales que de ese año adeudaba a la Corona, con excepción de dos mil sueldos o más, si fuesen necesarios, correspondientes al derecho de albaquía a utilizar "in refeccione cequie vel cequiarum orte loci predicti". CABEZUELO PLIEGO J. V. Documentos para la Historia del valle de Elda. 1356-1370, Elda, 1991, doc. 18. Cf. FERRER I MALLOL, M.․․ T. Les aljames sarraïnes ..., doc. 103.

(22) CABEZUELO PLIEGO, J.V. op. cit., pp. 141-144.

(23) ACA, C, reg. 728 , ff. 170v-171r. (1366, octubre, 5).

(24) ACA, C, reg. 726, f. 196r-v.

(25) ACA, C, reg. 728, f. $113 \mathrm{v}$.

(26) ACA, C, reg. 727, f. 138v.

(27) Apéndice documental, doc. 1.

(28) ACA, C, reg. 740 , ff. $148 v-149$ r. (1368, octubre, 14) y ACA, C, reg. 748 , ff. 178v-179v. (1370, junio, 10).

(29) ALBEROLA ROMÁ, A. y GIMÉNEZ LÓPEZ, E. "Establecimientos de tierra en el Camp d'Alacant tras la guerra de los dos Pedros", Congrés Internacional "Lluis de Santàngel y el seu temps", Valencia, 1897, en prensa. Gentileza de los autores.

(30) ACA, C, reg. 918, f. 130v. (1370, marzo, 6).

(31) ACA, C, reg. 752, f. 35r. (1370, julio, 8).

(32) ALBEROLA ROMA, A. y GIMÉNEZ LOPEZ, E. op. cit.

(33) ACA, C, reg. 1086, f. 64r.

(34) Apéndice documental, doc. 1.

(35) AMA, Armario 1, libro 2, ff. 6v-7r. Cf. HINOJOSA MONTALVO, J. Textos para la historia de Alicante, Historia Medieval, cap. II, 1, 84, pp. 226-227.

(36) Apéndice documental, doc. 1.

(37) AMA, Armario, 1, libro, 2, ff. 6v-7r. Cf. HINOJOSA MONTALVO, J. op. cit., cap. II, 1, 84, pp. 226-227.

(38) Apéndice documental, doc. 1.

(39) AMA, Armario 1, libro 2, f. 68r-v. Cf. HINOJOSA MONTALVO, J. op. cit., cap. II, 1, 84, p. 227.

(40) AMA, Armario 1, libro 2, f. 8r-v. Cf. HINOJOSA MONTALVO, J. op. cit., cap. I, 4, 44, pp. 155-156.

(41) Ya en 1374 se obtuvo una excelente cosecha de higos en la villa y término de Alicante, razón por la cual el infante don Juan, atendiendo a lo perecedero del producto, concedió a los alicantinos licencia para venderlos por todas las tierras de la Corona. HINOJOSA MONTALVO, J. op. cit., cap. II, 75, p. 216.

(42) GUTIÉRREZ LLORET, S. "La huerta medieval ....

(43) Según T. Glick dichos instrumentos de nivelación eran el nivell de pas, el en- 
treguart y la escuadra de carpintero. GLICK, T. Regadio y Sociedad en la Valencia Medieval, Valencia, 1988, p. 363.

(44) S.v. Conca en ALCOVER, A.M. ${ }^{a}$ Diccionari català-valencià-balear, III, Palma de Mallorca, 1979, pp. 361-362. También en COROMINES, J. Diccionari etimològic i complementari de la llengua catalana, II, Barcelona, 1981, pp. 865-867.

(45) Gualeró o goleró, como aparece referido con frecuencia en la documentación posterior (AMA, Arm. 2, lib. 11, fol. 3 y ss.) es un término catalán derivado de gola con el sentido de lloc profund on l'aigua és engolida. ALCOVER, A. M. a. op. cit, VI, p. 330 . Se trata, pues, de un caso en que la acequia acaba tomando por extensión el nombre de la propia boquera de donde nace. GUTIÉRREZ LLORET, S. "La huerta medieval ...

(46) ALBEROLA ROMA, A. El pantano de Tibi..., pp. 77-78.

(47) Ya expusimos con anterioridad los argumentos que permitían identificar este brazal con el de Benitía y relacionar el topónimo Aljucer con un área que debía sufrir periódicas inundaciones. GUTIÉRREZ LLORET, S. "La huerta y el alfoz ...", pp. 160-161.

(48) Así, la nueva acequia "...va a ferir al partidor de Benitía, e del dit partidor, passant lo braçal del Conchell, ha a passar per...", quizá por ser el que en origen desaguaba en el Conchell o cuenca del río el agua de avenida.

(49) ACA, C, reg. 340, f. 28v. (1296, mayo, 28), Cf. FERRER I MALLOL, M. ${ }^{\text {a }}$ T. Les aljames sarraïnes de la Governació d'Oriola en el segle XIV, Barcelona, 1988, p. 15.

(50) BARCELÓ, M. Arqueología medieval en las afueras del "medievalismo", Barcelona, 1988, p. 233 y ss.

(51) Por esta razón, como señalamos en un trabajo anterior (GUTIÉRREZ LLORET, S. "La huerta y el alfoz...", p. 157 y ss.), la acequia Mayor aparece mencionada en 1459 (ALBEROLA, A. y PATERNINA, M. a J. Ordenanzas Municipales de Alicante, 1459-1669, Alicante, 1989, pp. 55 y 83) como la cequia Vella e Nova, en clara referencia a la ampliación de un nuevo tramo de la acequia que fue considerado inicialmente un brazal, el de San Juan; nombre que desapareció rápidamente al considerarse este nuevo tramo parte de la vieja acequia Mayor. En el mismo sentido abunda el cronista Bendicho al indicar que la acequia Mayor llega con la misma fábrica hasta el lugar de San Juan. CABANÉS CATALÁ, M. a L. Chronica de la muy ilustre, noble y leal ciudad de Alicante, Alicante, 1990, pp. 131-132.

(52) Multa que en un primer momento era de veinte sueldos.

(53) La revisión y normalización de los textos al catalán moderno ha sido realizada por el Servei de Normalització Lingüística de la Universidad de Alicante. Agradecemos a la Dra. María Teresa Ferrer i Mallol, Directora de la Institució Milà Fontanals del C.S.I.C de Barcelona sus puntualizaciones gramaticales sobre ciertos términos del catalán medieval. Este artículo, y particularmente su apéndice documental, se ha beneficiado enormemente con las aclaraciones de la citada historiadora.

(54) Roto.

(55) Al final de la línea 61 hay una llamada.

(56) En el margen izquierdo aparece dibujada una mano cuyo dedo índice señala el inicio de la línea 69.

(57) Roto. 